\title{
A Study on the Relationship among Technology Spillovers, R\&D Investment and Firms' Cash Holdings
}

\author{
Jiayu Chi' ${ }^{1}$, Ling Sun ${ }^{2}$ \\ ${ }^{1}$ School of Business, Sun Yat-sen University, Guangzhou, China \\ ${ }^{2}$ Lingnan College, Sun Yat-sen University, Guangzhou, China \\ Email:chijiayu@mail.sysu.edu.cn
}

How to cite this paper: Chi, J.Y. and Sun, L. (2017) A Study on the Relationship among Technology Spillovers, R\&D Investment and Firms' Cash Holdings. Modern Economy, 8, 1609-1616.

https://doi.org/10.4236/me.2017.812107

Received: November 17, 2017

Accepted: December 24, 2017

Published: December 27, 2017

Copyright $(9) 2017$ by authors and Scientific Research Publishing Inc. This work is licensed under the Creative Commons Attribution International License (CC BY 4.0).

http://creativecommons.org/licenses/by/4.0/

\begin{abstract}
This study analyzes the relationship among technology spillovers, R\&D investment and firms' cash holdings. We find that technology spillovers and R\&D investment have a significant positive impact on the firms' cash holdings; and R\&D investment plays an intermediary role in technology spillovers' influence on firms' cash holdings.
\end{abstract}

\section{Keywords}

Technology Spillovers, R\&D Investment, Cash Holdings

\section{Introduction}

In recent years, firms increase their emphasis on technological innovation, For innovations are usually nonexclusive and unable to be monopolized by firms [1], there are considerable technology spillovers which could be generated through involuntary leakage and voluntary transmission [e.g., technological licensing]. So firms need to prepare adequate liquid cash to absorb knowledge diffusion as it arises and react to the threats from technology spillovers.

In this paper, we investigate the relationship among technology spillovers, $\mathrm{R} \& \mathrm{D}$ investment and firms' cash holdings. This study takes the A-share listed companies in China as the research object, and 767 sample firms' relevant financial data and patent data in the 2010-2015 periods are collected. We find that technology spillovers and R\&D investment have a significant positive impact on the firms' cash holdings; and R\&D investment plays an intermediary role in technology spillovers' influence on firms' cash holdings. 
The reminder of the paper proceeds as follows. In the next section, we develop the research model and propose hypotheses. Then, we describe the identification of technology spillovers and the data used for our study, and report the results of the data analysis. Finally, we discuss the major findings and their implications for research and practice.

\section{Hypothesis Development}

\subsection{Technology Spillovers and Cash Holdings}

According to the relevant research on technology spillovers, it can be found that external technology spillovers can help firms to improve their performance and productivity, thus helping firms to increase their profits. Firms can use their funds to absorb external knowledge diffusion. Existing literature provides strong evidence that technology spillovers enhance R\&D productivity [2] [3]. Jaffe [4] argues that technology spillovers have favorable externalities that can help companies acquire technology at a lower price than their own inventions, which can enhance their innovation and productivity. The more external technology spillovers, the more internal cash support companies need to absorb external knowledge. In addition, due to the instability of innovation activities, information asymmetry and the external financing constraints, companies also need more internal cash support.

At the same time, innovation will increase the inventor's competitive advantage and lead to market share competition, leading to the threat of product market. Firms' innovation will not only bring non-competitive technology spillovers, but also bring market competition. A large number of external technology spillovers will allow firms to feel a sense of crisis. Competitive threats from competitors' aggressive $R \& D$ behavior will make firms more focused on $R \& D$. In the face of huge external technology spillovers, companies are worried about whether their technology is out of date, fearing whether they are eliminated, companies have cash-held motivations to prevent themselves from cash shortages, which can lead to missed good investment opportunities and investment projects.

So the internal funds on the one hand can help firms to absorb knowledge diffusion, on the other hand to help companies deal with the threat of competition caused by technology spillovers. Qiu et al. [5] found that firms' cash holdings provided liquidity support for companies to absorb external technology spillovers, and technology spillover is one of the main factors influencing firms' cash holdings.

In summary, the greater the external technology spillover, companies will hold more cash. Therefore, this study makes the following hypothesis:

H1: Technology spillovers have a positive impact on firms' cash holdings.

\subsection{R\&D Investment and Cash Holdings}

R\&D investment activities are an important way for firms' strategic investment. $\mathrm{R} \& \mathrm{D}$ activities of firms can help firms to gain more competitive advantage and 
market share in the product market by creating knowledge and innovating technology. Guth et al. [6] found that R\&D investment in the firm would help it capture new markets and bring new profit growth points.

Transforming $R \& D$ investment motivation into real action requires the support of firms' funds. However, the high risk of $R \& D$ investment activities itself will bring high income uncertainty, that making it more difficult to obtain effective funding support from the external financing channels.

Himmelberg et al. [7] found that firms' R\&D investment would have some financial constraints, which would be more difficult to finance from corporate finance than other investments. They found that because of external financing constraints, companies will focus on taking into account the internal funds to carry out R\&D projects. Therefore, this study makes the following Hypothesis:

H2: R\&D investment has a positive impact on firms' cash holdings. The greater the R\&D investment, firms' cash holdings will be more.

\subsection{The Mediating Role of R\&D Investment}

The greater the spillover of technology outside the firm, the greater the R\&D investment the firm will provide to absorb the spillover. Spence [8] and Jaffe et al. [4] have found that technology spillovers affect $R \& D$ investment. In the face of external technology spillovers, companies will increase their R\&D investment to absorb external knowledge diffusion. The technology spillovers will have a significant positive impact on $R \& D$ investment. Technology spillovers can influence the R\&D investment of the firm and indirectly affect the cash holdings of the firm. Therefore, this study makes the following Hypothesis:

H3: The impact of technology spillovers on firms' cash holdings is mediated by firms' R\&D investment

Based on the above, this study presents the following research model, as shown in Figure 1.

\section{Variable Construction and Data Collection}

\subsection{Dependent Variable}

In this study, the dependent variable is the cash holdings of the firm, denoted as Cash. We use cash and cash equivalents over the total assets to measure the cash holdings [9] [10]. The value of the cash and cash equivalents is calculated using the sum of the monetary funds and the transactional financial assets in the balance sheet at the end of the year. The total assets are calculated using the total assets in the balance sheet at the end of the year.

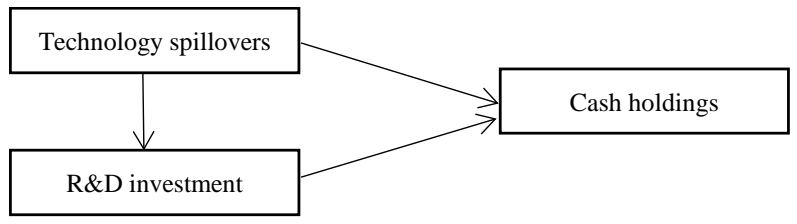

Figure 1. Research model. 


\subsection{Independent Variable}

1) Measuring technology spillovers

This study uses Jaffe [4] method to calculate the technology proximity between firms, and then use the technology proximity and the corresponding R\&D investment multiplication to calculate the firm's external technology spillovers.

First, by obtaining the application data of the firm under all the patent categories, construct the technical position vector of each firm:

$T e_{i}=\left(T e_{i 1}, T e_{i 2}, \cdots T e_{i n}\right)$;

Secondly, calculating the technology proximity between firms:

$$
\omega_{i j}=T e_{i} T e_{j}^{\prime} / \sqrt{T e_{i} T e_{i}^{\prime} \times T e_{j} T e_{j}^{\prime}}
$$

Thirdly, calculating the technological spill of firm $i$, which is equal to the sum of all other firms' R\&D inputs $r$ multiplied by the adjacent values of the corresponding technology;

$$
\text { spilltech }=\sum_{j \neq i} \omega_{i j} r_{j}
$$

Finally, we takes spilltech's natural logarithm as the measure of technology spillovers in the study, denoted as $\ln ($ Spill_Tech).

2) $R \& D$ investment

In this study, $R \& D$ investments are measured by the ratio of $R \& D$ expenses to total assets, denoted as R\&D-Invest.

\subsection{Control Variable}

Following the literature on the construction of other explanatory variables of cash holdings, we added control variables such as the scale of firms, asset-liability ratio, net working capital and ROA (Return On Assets) in this study.

1) The scale of firms: This study measures the scale of firms by taking the natural logarithm of the total assets of the firm, denoted as $\ln$ (Total-Asset).

2) Asset-liability ratio: This study uses the ratio of total liabilities to total assets to calculate the asset-liability ratio, denoted as Asset-Liability-Ratio.

3) Net working capital: This study measures the net operating capital by subtracting current liabilities from current assets minus the ratio of cash and cash equivalents to total assets, denoted as Net-Capital.

4) ROA: ROA is equal to the ratio of after-tax income (plus interest) to total assets.

\subsection{Samples and Data Sources}

Based on the data of A-share listed companies from 2010 to 2015 in China, the original samples are screened according to following principles:

1) Due to the particularity of financial firms, this study does not consider the financial firms, to remove the samples;

2) Excluding the financial situation or other conditions of the abnormal ST firms;

3) Excluding the firms whose financial data related to major variables are 
missing;

4) Due to the technical spillover variables in this study need to use the patent data, the 2010-2015 no patent-related data companies to be removed.

After the above method of screening, finally, we get the related financial and patent data of 767 listed companies in 2010-2016. Relevant data sources are mainly Csmar database and National Patent and Intellectual Property Office database.

\section{Data Analysis and Results}

\subsection{Descriptive Statistics}

Table 1 reports the mean, standard deviation, minimum and maximum values for each variable in this paper.

In this study, the correlation between the study variables was analyzed by Pearson correlation analysis. The correlation coefficients between the study variables are shown in Table 2.

The results of the analysis in Table 2 show that the technology spillover is positively correlated with the cash holding at a level of $1 \%$. There is a significant positive correlation between the R\&D investment and the cash holding at $1 \%$ level, and the technology spillover and R\&D investment were significantly positively correlated at $1 \%$ level. This suggests that the relationship between variables is consistent with the assumptions presented in this study.

\subsection{Regression Analysis}

In order to verify the impact of technology spillovers and firms' R\&D investment on firms' cash holdings, this study is divided into two stages. In the first stage, the relationship between technology spillovers, firms' $R \& D$ investment and firms' cash holdings is first examined, then the hypothesis 1 and the hypothesis 2 to verify. In the second stage, Baron and Kenny's stepwise method is used to test hypothesis 3, that is, the mediating role of $\mathrm{R} \& \mathrm{D}$ investment in the impact of technology spillovers on cash holdings (Table 3). Our regression model is specified as:

Table 1. The descriptive statistics of variables.

\begin{tabular}{cccccc}
\hline Variable type & Variable & Mean & SD & Min & Max \\
\hline Dependent variable & Cash & 0.227 & 0.132 & 0.01 & 0.825 \\
Independent variable & $\ln$ (Spill_Tech) & 13.345 & 0.787 & 8.89 & 14.533 \\
& R\&D-Invest & 0.017 & 0.016 & 0.0001 & 0.205 \\
& ln(Total-Asset) & 12.659 & 1.086 & 10.079 & 17.741 \\
Control variable & Asset-Liability-Ratio & 0.394 & 0.196 & 0.036 & 1.04 \\
& Net-Capital & 0.048 & 0.165 & -0.578 & 0.469 \\
& ROA & 0.044 & 0.044 & -0.214 & 0.252 \\
\hline
\end{tabular}


Table 2. The correlation analysis of variables.

\begin{tabular}{lccccccc}
\hline & 1 & 2 & 3 & 4 & 5 & 6 & 7 \\
\hline 1) Cash & 1 & & & & & & \\
2) $\ln$ (Spill_Tech) & $0.111^{* * *}$ & 1 & & & & & \\
3) R\&D-Invest & $0.25^{* * *}$ & $0.238^{* * *}$ & 1 & & & & \\
4) $\ln$ (Total-Asset) & $-0.321^{* * *}$ & 0.044 & $-0.186^{* * *}$ & 1 & & & \\
5) Asset-Liability-Ratio & $-0.621^{* * *}$ & -0.023 & $-0.255^{* * *}$ & $0.57^{* * *}$ & 1 & & \\
6) Net-Capital & $0.301^{* * *}$ & $0.133^{* * *}$ & $0.256^{* * *}$ & $-0.415^{* * *}$ & $-0.709^{* * *}$ & 1 & \\
7) ROA & $0.363^{* * *}$ & 0.038 & $0.27^{* * *}$ & -0.017 & $-0.481^{* * *}$ & $0.394^{* * *}$ & 1 \\
\hline
\end{tabular}

Notes. ${ }^{* *} \mathrm{p}<0.1 ;{ }^{* *} \mathrm{p}<0.05 ;{ }^{* *} \mathrm{p}<0.01$.

Table 3. Regression analysis results.

\begin{tabular}{|c|c|c|c|c|}
\hline & Model 1 & Model 2 & Model 3 & Model 4 \\
\hline $\ln$ (Total-Asset) & $\begin{array}{c}0.000574 \\
(0.13)\end{array}$ & $\begin{array}{c}-0.000927 \\
(-0.22)\end{array}$ & $\begin{array}{c}0.00258 \\
(0.60)\end{array}$ & $\begin{array}{c}0.000796 \\
(0.18)\end{array}$ \\
\hline Asset-Liability-Ratio & $\begin{array}{c}-0.528^{* * *} \\
(-16.45)\end{array}$ & $\begin{array}{c}-0.535^{* * *} \\
(-16.92)\end{array}$ & $\begin{array}{c}-0.530^{* * *} \\
(-16.67)\end{array}$ & $\begin{array}{c}-0.536^{* * *} \\
(-17.02)\end{array}$ \\
\hline Net-Capital & $\begin{array}{c}-0.234^{\star * *} \\
(-7.50)\end{array}$ & $\begin{array}{c}-0.260^{* * *} \\
(-8.31)\end{array}$ & $\begin{array}{c}-0.245^{\star * *} \\
(-7.89)\end{array}$ & $\begin{array}{c}-0.264^{* * *} \\
(-8.49)\end{array}$ \\
\hline ROA & $\begin{array}{c}0.304^{\star * *} \\
(3.04)\end{array}$ & $\begin{array}{c}0.309^{* * *} \\
(3.13)\end{array}$ & $\begin{array}{c}0.226^{\star *} \\
(2.24)\end{array}$ & $\begin{array}{c}0.250^{* *} \\
(2.49)\end{array}$ \\
\hline $\ln ($ Spill_Tech) & & $\begin{array}{c}0.0222^{* * *} \\
(4.84)\end{array}$ & & $\begin{array}{c}0.0190^{\star * *} \\
(4.04)\end{array}$ \\
\hline R\&D-Invest & & & $\begin{array}{c}0.950^{* * *} \\
(3.90)\end{array}$ & $\begin{array}{c}0.712^{* * *} \\
(2.87)\end{array}$ \\
\hline _cons & $\begin{array}{c}0.425^{\star * \star} \\
(8.70)\end{array}$ & $\begin{array}{l}0.152^{* *} \\
(2.04)\end{array}$ & $\begin{array}{c}0.389^{* * *} \\
(7.88)\end{array}$ & $\begin{array}{l}0.164^{\star *} \\
(2.21)\end{array}$ \\
\hline$N$ & 767 & 767 & 767 & 767 \\
\hline$R$-square & 0.4335 & 0.4504 & 0.4446 & 0.4563 \\
\hline
\end{tabular}

Notes. ${ }^{* *} \mathrm{p}<0.1 ;{ }^{* *} \mathrm{p}<0.05 ;{ }^{* * *} \mathrm{p}<0.01$.

$$
\text { Cash }_{i}=\beta_{0}+\beta_{1} \ln \left(\text { Spill }_{-} \text {Tech }_{i}\right)+\beta_{2}\left(\mathrm{R} \& \mathrm{D}-\text { Invest }_{\mathrm{i}}\right)+\varepsilon_{i}
$$

In model 1, only the control variables are added as a reference model to examine the effect of each explanatory variable on firms' cash holdings. Model 2 adds technical spillovers over the model 1 to verify that the technology spillovers the firms' cash. There is a positive impact on the assumption that the model 3 on the basis of the model 1 to join the R\&D investment variable to test the R\&D investment has a positive impact on firms' cash holdings of the assumption.

In model 1 , there are three control variables that have a significant positive impact on cash holdings, except for total asset.

In model 2, the regression coefficient of technology spillovers for firms' cash is 0.0222 and significant at $1 \%$ level, and it can be seen that technological spillovers 
have a significant positive effect on firms' cash holdings. The more the technology spillover, the more firms' cash is held, verifying the hypothesis 1 . This shows that the greater the technology spillovers, companies will have a stronger motivation to hold more cash. Firms will increase their cash holdings in order to absorb technology spillovers outside the firm, to improve innovation performance and productivity. In the face of greater technology spillovers, companies may face greater competition threats, which will lead firms to increase their cash holdings.

In model 3, the coefficient of return of firms' R\&D investment to firms' cash is 0.950 and significant at $1 \%$ level. It can be seen that R\&D investment has a significant positive impact on firms' cash holdings. The more R\&D investment, the more firms' cash holdings, verify the hypothesis 2 . This shows that the greater the R\&D investment, companies will have motivation to hold more cash. Firms' $R \& D$ activities itself is uncertain, so they are not certainly able to obtain effective external financial support. Therefore, when firms have greater R\&D investment, they need more internal cash support, that will bring greater cash holdings.

In model 4 , after adding the R\&D input variables, the impact of $R \& D$ investment on firms' cash holdings is significant at $1 \%$ level, and it can be seen that $\mathrm{R} \& \mathrm{D}$ investment plays an intermediary role in the impact of technology spillovers on firms' cash holdings. At the same time, the impact of technology spillovers on firms' cash holdings is still significant, and it can be seen that the R\&D investment is the partial intermediary effect on the impact of technology spillovers on firms' cash holdings, verify the hypothesis 3 . This shows that firms face greater external technology spillover will increase their own R\&D investment, which will affect the company's cash holdings, so that firms hold more cash.

\section{Conclusions}

This study takes the Chinese A-share listed companies as the empirical research object, and analyzes the relationship among technology spillover, R\&D investment and firms' cash holding. We find that technology spillovers and R\&D investment have significant positive impacts on the firms' cash holdings; and R\&D investment plays an intermediary role in technology spillovers' influence on firms' cash holdings. The research of this paper enriches the researches on the relationship between technology innovation and firms' cash holdings.

The shortcomings of this study are that: the conceptual model of this study is relatively simple; there are many factors that affect the firms' cash holdings, such as market competition, financing constraints, etc.; they may also have the relationship between technology spillover and cash holdings. This study did not discuss the impact of these factors. They can be left for future research.

\section{References}

[1] Griliches, Z. (1991) The Search for R\&D Spillovers. Scandinavian Journal of Economics, 94, 29-47. https://doi.org/10.2307/3440244 
[2] Griliches, Z. (1979) Issues in Assessing the Contribution of Research and Development to Productivity Growth. Bell Journal of Economics, 10, 92-116. https://doi.org/10.2307/3003321

[3] Tambe, P. and Hitt, L.M. (2014) Job Hopping, Information Technology Spillovers, and Productivity Growth. Management Science, 60, 338-355. https://doi.org/10.1287/mnsc.2013.1764

[4] Jaffe, A.B. (1986) Technological Opportunity and Spillovers of R\&D: Evidence from Firms' Patents, Profits, and Market Value. American Economic Review, 26, 1023-1046.

[5] Qiu, J. and Wan, C. (2015) Technology Spillovers and Corporate Cash Holdings. Journal of Financial Economics, 115, 558-573. https://doi.org/10.1016/j.jfineco.2014.10.005

[6] Guth, W.D. and Ginsberg, A. (1990) Guest Editors' Introduction: Corporate Entrepreneurship. Strategic Management Journal, 19, 24-25.

[7] Himmelberg, C.P. and Petersen, B.C. (1994) R\&D and Internal Finance: A Panel Study of Small Firms in High-Tech Industries. The Review of Economics and Statistics, 76, 38-51. https://doi.org/10.2307/2109824

[8] Spence, M. (1984) Cost Reduction, Competition and Industry Performance. Econometrica, 52, 101-121. https://doi.org/10.2307/1911463

[9] Kim, C.S., Mauer, D.C. and Sherman, A.E. (1998) The Determinants of Corporate Liquidity: Theory and Evidence. Journal of Financial \& Quantitative Analysis, 33, 335-359. https://doi.org/10.2307/2331099

[10] Guney, Y., Ozkan, A. and Ozkan, N. (2007) International Evidence on the Non-Linear Impact of Leverage on Corporate Cash Holdings. Journal of Multinational Financial Management, 17, 45-60.

https://doi.org/10.1016/j.mulfin.2006.03.003 